\title{
A Bibliography of Douglas Walton's Published Works, 1971-2007
}

Produced by David Godden, this bibliography is based on the list of publications in Douglas Walton's curriculum vitae. It is printed here with Professor Walton's consent. For a complete list of Professor Walton's publications, see his webpage: http://io.uwinnipeg.ca/ walton/. The 2007 entries include only January-April, 2007.

Items are listed in reverse chronological order by calendar year. Within each year, items are listed in the following groups:

$$
\begin{aligned}
& \mathbf{B}=\text { Books } \\
& \mathbf{J}=\text { Journal articles } \\
& \mathbf{E}=\text { Contributions to edited volumes } \\
& \mathbf{P}=\text { Published conference proceedings }
\end{aligned}
$$

Within each group, items are listed alphabetically by title, first publications with no author named, which are authored by Douglas Walton alone, followed by co-authored items, listed alphabetically by co-author.

Other abbreviations of journals referenced in the bibliography are:

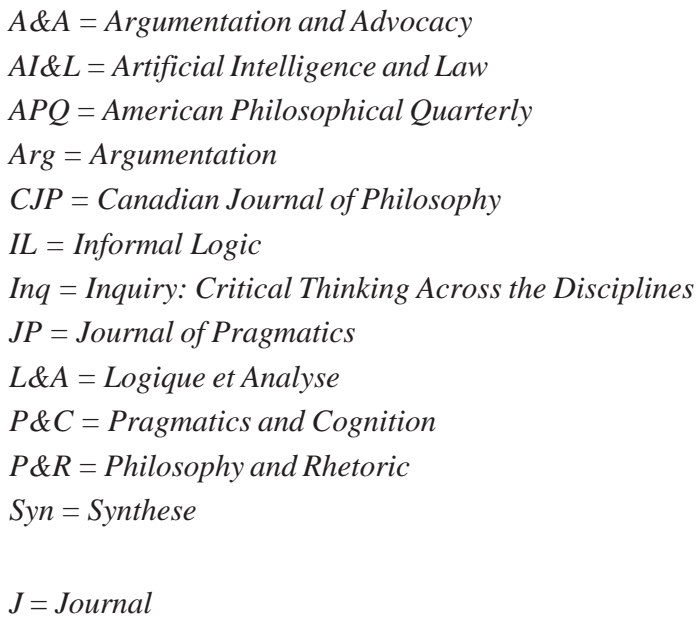

The following are abbreviations of publishers' names:

CUP $=$ Cambridge University Press

ISSA = International Society for the Study of Argumentation

LEA $=$ Lawrence Erlbaum Associates

OUP $=$ Oxford University Press

OSSA = Ontario Society for the Study of Argumentation

PSUP $=$ The Pennsylvania State University Press

SUNY $=$ State University of New York Press 


\section{7 \& Forthcoming}

B (forthcoming). Media Argumentation: Dialectic, Persuasion and Rhetoric. New York: CUP. (forthcoming). Witness Testimony Evidence: Argumentation, Artificial Intelligence and Law. New York: CUP.

Walton, D., Macagno, F. \& Reed. C. (forthcoming). Argumentation Schemes. New York: CUP.

J (forthcoming). A commitment search tool for the straw man fallacy. IL.

(forthcoming). Evaluating practical reasoning. Syn.

Walton, D. \& Godden, D.M. (2007). A theory of presumption for everyday argumentation. $P \& C, 15,313-346$.

Walton, D. \& Godden, D.M. (forthcoming). Advances in the theory of argumentation schemes and critical questions. IL.

Walton, D., Gordon, T. \& Prakken, H. (forthcoming).The Carneades model of argument and burden of proof. Artificial Intelligence.

Walton, D. \& Macagno, F. (forthcoming). Persuasion strategies of quotation manipulation. Inq.

Walton, D. \& Macagno, F. (forthcoming). Wrenching from context: The manipulation of commitments. Arg.

Walton, D., Macagno, F. \& Reed, C. (forthcoming). Argument diagramming in logic, law and artificial intelligence. Knowledge Engineering Review.

\section{6}

B (2006). Character Evidence: An Abductive Theory. Berlin: Springer.

(2006). Fundamentals of Critical Argumentation. New York: CUP.

J (2006). Argument from appearance: A new argumentation scheme. $L \& A, 195,319-340$.

(2006). Epistemic and dialectical models of begging the question. Syn, 152, 237-284.

(2006). Examination dialogue: An argumentation framework for critically questioning an expert opinion. $J P, 38,745-777$.

(2006). How to make and defend a proposal in deliberation dialogue. AI\&L, 14, 177 239.

(2006). Poisoning the well. Arg, 20, 273-307.

(2006). Rules for reasoning from knowledge and lack of knowledge. Philosophia, 34, 355-376.

(2006). Using conversation policies to solve problems of ambiguity in argumentation and artificial intelligence. $P \& C, 14,3-36$.

Walton, D. \& Godden, D.M. (2006). Argument from expert opinion as legal evidence: Critical questions and admissibility criteria of expert testimony in the American legal system. Ratio Juris, 19, 261-286.

Walton, D. \& Macagno, F. (2006). Common knowledge in argumentation. Studies in Communication Sciences, 6, 3-26.

Walton, D., Macagno, F., Reed, C., \& Rowe, G. (2006). Araucaria as a tool for diagramming arguments in teaching and studying philosophy. Teaching Philosophy, 29, 111-124.

Walton, D. \& Schafer, B. (2006). Arthur, George and the mystery of the missing motive: Towards a theory of evidentiary reasoning about motives. International Commentary on Evidence, 4, 1-47.

E Walton, D. \& Godden, D.M. (2006). The impact of argumentation on artificial intelligence. In P. Houtlosser \& A. van Rees (Eds.), Considering Pragma-Dialectics (pp. 287-299). Mahwah, NJ: LEA.

P (2006). Disagreement space, burden of proof and fallacies. In P. Riley (Ed.), Engaging Argument: Selected Papers from the 2005 NCA/AFA Summer Conference on Argumentation (pp. 426431). Washington DC: National Communication Association. 
Walton, D. \& Godden, D.M. (2006). Alternatives to suspicion and trust as conditions for challenge in argumentative dialogue. In P. Riley (Ed.), Engaging Argument: Selected Papers from the 2005 NCA/AFA Summer Conference on Argumentation (pp. 438-444). Washington DC, National Communication Association.

Walton, D. \& Gordon, T. (2006). The Carneades argumentation framework: Using presumptions and exceptions to model critical questions. In Proceedings of $6^{\text {th }}$ CMNA (Computational Models of Natural Argument) Workshop, ECAI (European Conference on Artificial Intelligence), Riva del Garda, Italy, August 28 - September 1 (pp. 5-13). Trento, Italy: University of Trento.

Walton, D. \& Gordon, T. (2006). The Carneades argumentation framework: Using presumptions and exceptions to model critical questions. In P. Dunne \& T. Bench-Capon (Eds.), Computational Models of Argument: Proceedings of COMMA 2006 (pp. 195-207). Amsterdam: IOS Press.

Walton, D. \& Gordon, T. (2006). Pierson v. Post revisited. In P. Dunne \& T. Bench-Capon (Eds.), Computational Models of Argument: Proceedings of COMMA 2006 (pp. 208-219). Amsterdam: IOS Press.

Walton, D. \& Macagno, F. (2006). Argumentative reasoning patterns. Proceedings of $6^{\text {th }}$ CMNA (Computational Models of Natural Argument) Workshop, ECAI(European Conference on Artificial Intelligence), Riva del Garda, Italy, August 28 - September 1 (pp. 48-51). Trento, Italy: University of Trento.

Walton, D. \& Reed, C. (2006). Evaluating corroborative evidence. In Proceedings of the Sixth Conference of the ISSA (pp. 881-885). Amsterdam: SicSat.

\section{5}

B (2005). Argumentation Methods for Artificial Intelligence in Law. Berlin: Springer.

J (2005). An automated system for argument invention in law using argumentation and heuristic search procedures. Ratio Juris, 18, 434-463.

(2005). Begging the question in arguments based on testimony. Arg, 19, 85-113.

(2005). Deceptive arguments containing persuasive language and persuasive definitions. Arg, $19,159-186$

(2005). How to evaluate argumentation using schemes, diagrams, critical questions and dialogues. Studies in Communication Sciences, Special Issue M. Dascal et. al. (Eds.), Argumentation in Dialogic Interaction, 51-74.

(2005). Justification of argumentation schemes. The Australasian J of Logic, 3, 1-13.

(2005). Pragmatic and idealized models of knowledge and ignorance. $A P Q, 42,59-69$.

Walton, D. \& Godden, D.M. (2005). Persuasion dialogue in online dispute resolution. $A I \& L$, $13,273-295$.

Walton, D. \& Macagno, F. (2005). Common knowledge in legal reasoning about evidence. International Commentary on Evidence, 3, 1-42

Walton, D. \& Reed, C. (2005). Argumentation schemes and enthymemes. Syn, 145, 339-370.

Walton, D. \& Reed, C. (2005). Towards a formal and implemented model of argumentation schemes in agent communication. Autonomous Agents and Multi-Agent Systems, 11, 173188.

E (2005). Practical reasoning [revised version]. In P.H. Werhane \& R.E. Freeman (Eds.), The Blackwell Encyclopedia of Management, $2^{\text {nd }}$ ed., vol. 2 Business Ethics (pp. 414-415). Oxford: Blackwell.

(2005). Practical reasoning and proposing: Tools for e-democracy. In M. Moens \& P. Spyns (Eds.), Legal Knowledge and Information Systems (pp. 113-114). Amsterdam: IOS Press. Walton, D. \& Reed, C. (2005). Towards a formal and implemented model of argumentation schemes in agent communication. In I. Rahwan, P. Moraitis \& C. Reed (Eds.), Argumentation 
in Multi-Agent Systems: First International Workshop, ArgMAS 2004, Revised Selected and Invited Papers (pp. 19-30). Berlin: Springer.

P (2005). Evaluating practical reasoning. In Proceedings of the Conference on Norms, Knowledge and Reasoning in Technology Held at Huis Elzendaal, Boxmeer, the Netherlands, June 3-4, 2005. Eindhoven: Technical University of Eindhoven.

Walton, D. \& Godden, D.M. (2005). The nature and status of critical questions in argumentation schemes. In D. Hitchcock \& D. Farr (Eds.), The Uses of Argument: Proceedings of a Conference at McMaster University (pp. 476-484). Hamilton, ON: OSSA.

Walton, D. \& Gordon, T. (2005). Critical questions in computational models of legal argument.

In P. Dunne \& T. Bench-Capon (Eds.), International Workshop on Argumentation in Artificial Intelligence and Law (IAAIL) Workshop Series (pp. 103-111). Nijmegen: Wolf Legal Publishers.

Walton, D. \& Lodder, A.R. (2005). What role can rational argument play in ADR and Online Dispute Resolution? In J. Zelzniknow \& A.R. Lodder (Eds.), IAAIL Workshop Series, Second International ODR Workshop (pp. 69-76). Nijmegen: Wolf Legal Publishers.

Walton, D., Prakken, H. \& Reed, C. (2005). Dialogues about the burden of proof. In Proceedings of the Tenth International Conference on Artificial Intelligence and Law, Held June 6-11, 2005 in Bologna, Italy (pp. 115-124). New York: The Association for Computing Machinery (ACM).

\section{4}

B (2004). Abductive Reasoning. Tuscaloosa, AB: University of Alabama Press.

(2004). Relevance in Argumentation. Mahwah, NJ: LEA.

Walton, D., Lodder, A.R. et. al. (Eds.) (2004). Essays on Legal and Technical Aspects of Online Dispute Resolution: Papers from the ICAIL 2003 ODR Workshop, June 28, 2003, Edinburgh. Amsterdam: Centre for Electronic Dispute Resolution.

J (2004). A new dialectical theory of explanation. Philosophical Explorations, 7, 71-89.

(2004). Argumentation schemes and historical origins of the circumstantial ad hominem argument.

Arg, 18, 359-368.

(2004). Classification of fallacies of relevance. IL, 24, 71-103.

Walton, D. \& Godden, D.M. (2004). Denying the antecedent as a legitimate argumentative strategy: A dialectical model. IL, 24, 219-243.

E (2004). Criteria of rationality for evaluating democratic public rhetoric. In B. Fontana, C.J.

Nederman \& G. Remer (Eds.), Talking Democracy: Historical Perspectives on Rhetoric and Democracy (pp. 295-330). University Park, PA: PSUP.

P Walton, D., Prakken, H. \& Reed, C. (2004). Argumentation schemes and burden of proof. In F. Grasso, C. Reed \& G. Carenini (Eds.), Working Notes of the $4^{\text {th }}$ International Workshop on Computational Models of Natural Argument (CMNA 2004). Valenca: CMNA.

\section{3}

J (2003). Argumentation schemes: The basis of conditional relevance. Michigan State Law Review, 2003(4), 1205-1242.

(2003). Defining conditional relevance using linked arguments and argumentation schemes.

Michigan State DCL Law Review, 2003(4), 1305-1314.

(2003). The interrogation as a type of dialogue. JP, 35, 1771-1802.

(2003). Is there a burden of questioning? AI\&L, 11, 1-43.

Walton, D., Bex, F., Prakken, H. \& Reed, C. (2003). Towards a formal account of reasoning about evidence, argument schemes and generalizations. AI\&L, 11, 125-165.

E Walton, D., Carbogim, D.V., Krabbe, E.C.W. \& Norman, T. (2003). Argument and multi-agent systems. In C. Reed \& T.J. Norman (Eds.) Argumentation Machines: New Frontiers in Argument and Computation (pp. 15-54). Dordrect: Kluwer. 
Walton, D. \& Reed, C. (2003). Diagramming, argumentation schemes and critical questions. In F.H. van Eemeren et. al. (Eds.), Anyone Who Has a View: Theoretical Contributions to the Study of Argumentation (pp. 195-211). Dordrecht: Kluwer.

P (2003). Commentary on E. Feteris: 'Arguments from unacceptable consequences and a reasonable application of law'. In J.A. Blair et. al. (Eds.), IL @ 25: Proceedings of the Windsor Conference, CD-ROM. Windsor, ON: OSSA.

(2003). Informal logic 25 years later. In J.A. Blair et.al. (Eds.), IL @ 25: Proceedings of the Windsor Conference, CD-ROM. Windsor, ON: OSSA.

Walton, D., Prakken, H. \& Reed, C. (2003). Argumentation schemes and generalisations in reasoning about evidence. In Proceedings of the Conference: The $9^{\text {th }}$ International Conference on Artificial Intelligence and Law, University of Edinburgh (pp. 32-41). New York:

Association for Computing Machinery (ACM).

Walton, D. \& Reed, C. (2003). Applications of argumentation schemes. In H.V. Hansen et. al. (Eds.), Argumentation and Its Applications: Proceedings of the 4th OSSA Conference, CDROM. Windsor, ON: OSSA.

Walton, D. \& Reed, C. (2003). Argumentation schemes in argument-as-process and argumentas-product. In J.A. Blair et. al. (Eds.), IL @ 25: Proceedings of the Windsor Conference, CD-ROM. Windsor, ON: OSSA.

Walton, D. \& Reed, C. (2003). Diagramming argumentation schemes and critical questions. In F.H. van Eemeren et. al. (Eds.), Proceedings of the Fifth Conference of the ISSA (pp. 881885). Amsterdam: SicSat.

\section{2}

B (2002). Ethical Argumentation. Lanham, MD: Lexington Books. (2002). Legal Argumentation and Evidence. University Park, PA: PSUP.

J (2002). Are some modus ponens arguments deductively invalid? IL, 22, 19-46. (2002). The sunk costs fallacy or argument from waste. Arg, 16, 473-503.

E (2002). Author's preface. In Russian translation Ad Hominem Arguments [Originally published (1998) University of Alabama Press.] (pp. 13-14). Moscow: Institute of Sociology of the Russian Academy of Sciences.

\section{1}

J (2001). Abductive, presumptive and plausible arguments. IL, 21, 141-169.

(2001). Enthymemes, common knowledge and plausible inference. $P \& R, 34,93-112$.

(2001). Johnstone's view of rhetorical and dialectical argument. IL, 21, 51-60.

(2001). Persuasive definitions and public policy arguments. A\&A, 37, 117-132.

(2001). Searching for the roots of the circumstantial ad hominem. Arg, 15, 207-221.

E (2001). Ad hominem argument. In T.O. Sloane (Ed.), Encyclopedia of Rhetoric (pp. 1-4). Oxford: OUP.

(2001). Courage [revised version]. In L.C. Becker \& C.B. Becker (Eds.), Encyclopedia of Ethics, vol. 1, 2nd ed. (pp. 352-355). New York: Routledge.

(2001). Practical reason(ing) [revised version]. In L.C. Becker \& C.B. Becker (Eds.), Encyclopedia of Ethics, vol. 1, 2nd ed. (pp. 1355-1358). New York: Routledge.

(2001). Persuasive definition. In L.C. Becker \& C.B. Becker (Eds.), Encyclopedia of Ethics, vol. 1, 2nd ed. (pp. 1303-1305). New York: Routledge.

\section{0}

B (2000). Scare Tactics: Arguments that Appeal to Fear and Threats. Dordrecht: Kluwer. Walton, D., Irvine, A. \& Woods, J. (2000). Argument, Critical Thinking, Logic and the Fallacies.Toronto:PrenticeHall. [Revised and expanded edition of Argument: The Logic of the Fallacies (1982).] 
J (2000). Alfred Sidgwick: A little-known precursor of informal logic and argumentation. Arg, $14,175-179$.

(2000). Case study of the use of the circumstantial ad hominem in political argumentation. $P \& R, 33,101-115$.

(2000). Evaluating appeals to popular opinion. Inq, 20, 33-45.

(2000). New dialectical rules for ambiguity. IL, 20, 261-274.

(2000). Problems and useful techniques: My experience in teaching courses in argumentation, informal logic and critical thinking. IL, 20, TS35-TS38.

(2000). The place of dialogue theory in logic, computer science and communication studies. Syn, 123, 327-346.

(2000). Use of ad hominem argument in political discourse: The Battalino case from the impeachment trial of President Clinton. A\&A, 36, 179-195.

E (2000). Argumentation and theory of evidence. In C.M. Breur et. al. (Eds.), New Trends in Criminal Investigation and Evidence, vol. 2 (pp. 711-732). Antwerp: Intersentia.

(2000). Conversational logic and appeals to emotion. In C. Plantin, M. Doury \& V. Traverso (Eds.), Les Emotions dans les Interactions (pp. 295-312). Lyon: Presses Universitaires de Lyon.

\section{9}

B (1999). Appeal to Popular Opinion. University Park, PA: PSUP.

(1999). One-Sided Arguments: A Dialectical Analysis of Bias. Albany, NY: SUNY.

(1999). Slippery Slope Arguments. Newport News, VA: Vale Press. [Reprint of Slippery Slope Arguments (1992).]

J (1999). Applying labelled deductive systems and multi-agent systems to source-based argumentation. $J$ of Logic and Computation, 9, 63-80.

(1999). Can an ancient argument of Carneades on cardinal virtues and divine attributes be used to disprove the existence of God? Philo, 2, 5-13.

(1999). Dialectical relevance in persuasion dialogue. IL, 19, 119-143.

(1999). Ethotic arguments and fallacies: The credibility function in multi-agent dialogue systems. $P \& C, 7,177-203$.

(1999). Francis Bacon: Human bias and the four idols. Arg, 13, 385-389.

(1999). Historical origins of argumentum ad consequentiam. Arg, 13, 251-264.

(1999). Peter Ramus. Arg, 13, 391-392.

(1999). Profiles of dialogue for evaluating arguments from ignorance. Arg, 13, 53-71.

(1999). Rethinking the fallacy of hasty generalization. Arg, 13, 161-182.

(1999). The appeal to ignorance, or argumentum ad ignorantiam. Arg, 13, 367-377.

(1999). The fallacy of many questions: On the notions of complexity, loadedness and unfair entrapment in interrogative theory. Arg, 13, 379-383.

(1999). The new dialectic: A method of evaluating an argument used for some purpose in a given case. Protosociology, 13, 70-91.

E (1999). Informal fallacy [Entry for]. In R. Audi (Ed.), The Cambridge Dictionary of Philosophy, 2nd ed. (pp. 431-435). New York: CUP.

(1999). Informal logic [Entry for]. In R. Audi (Ed.), The Cambridge Dictionary of Philosophy, ed. 2nd ed. (p. 435). New York: CUP.

P (1999). The identity crisis of informal logic. In F.H. van Eemeren et. al. (Eds.), Proceedings of the Fourth International Conference of the ISSA (pp. 853-857). Amsterdam: SicSat.

\section{8}

B (1998). Ad Hominem Arguments. Tuscaloosa, AB: University of Alabama Press. 
(1998). The New Dialectic: Conversational Contexts of Argument. Toronto: University of Toronto Press.

J (1998). A pragmatic model of legal disputation. Notre Dame Law Review, 73, 711-735.

E (1998). Fallacies. In E. Craig (Ed.), Routledge Encyclopedia of Philosophy, vol. 3 (pp. $544-$ 545). London: Routledge.

(1998). Formal and informal logic. In E. Craig (Ed.), Routledge Encyclopedia of Philosophy, vol. 3 (pp. 701-703). London: Routledge.

\section{7}

B (1997). Appeal to Expert Opinion: Arguments from Authority. University Park, PA: PSUP. (1997). Appeal to Pity: Argumentum Ad Misericordiam. Albany, NY: SUNY.

Walton, D. \& Brinton, A. (Eds.). (1997). Historical Foundations of Informal Logic. Aldershot, GB: Ashgate Publishing.

J (1997). How can logic best be applied to arguments? Logic J of the IGPL (Interest Group on

Pure and Applied Logic), 5, 603-614.

(1997). Judging how heavily a question is loaded: A pragmatic method. Inq, 17, 53-71.

(1997). What is propaganda, and exactly what is wrong with it? Public Affairs Quarterly, 11, 383-413.

E (1997). Actions and inconsistency: The closure problem of practical reasoning. In G. HolmstromHintikka \& R. Tuomela (Eds.), Contemporary Action Theory, vol. 1 (pp. 159-175). Dordrecht: Kluwer.

(1997). Practical reasoning. In P.H. Werhane \& R.E. Freeman (Eds.), The Blackwell Encyclopedic Dictionary of Business Ethics (pp. 495-496). Oxford: Blackwell.

Walton, D. \& Brinton, A. (1997). Introduction. In D. Walton \& A. Brinton (Eds.), Historical Foundations of Informal Logic (pp. 1-11). Aldershot, GB: Ashgate Publishing.

Walton, D. \& Woods, J. (1997). Argumentum ad verecundiam. In F.H. van Eemeren \& R.

Grootendorst (Eds.), Studies Over Argumentatie (pp. 191-210). Amsterdam: Boom. [Dutch translation of Walton and Woods (1974).]

\section{6}

B (1996). Argument Structure: A Pragmatic Theory. Toronto: University of Toronto Press. (1996). Argumentation Schemes for Presumptive Reasoning. Mahwah, NJ: LEA. (1996). Arguments from Ignorance. University Park, PA: PSUP. (1996). Fallacies Arising from Ambiguity. Dordrecht: Kluwer.

J (1996). New methods for evaluating arguments. Inquiry: Critical Thinking Across the Disciplines, 15, 44-65

(1996). Plausible deniability and the evasion of burden of proof. Arg, 10, 47-58.

(1996). Practical reasoning and the structure of fear appeal arguments. $P \& R, 29,301-313$.

(1996). The argument of the beard. $I L, 18,235-259$.

(1996). The witch hunt as a structure of argumentation. Arg, 10, 389-407.

E (1996). The straw man fallacy. In J. van Bentham et. al. (Eds.), Logic and Argumentation (pp. 115-128). Amsterdam: Royal Netherlands Academy of Arts and Sciences.

Walton, D. \& Woods, J. (1996). Fallacies and formal logic. In F.H. van Eemeren, et. al. (Eds.), Fundamentals of Argumentation Theory (pp. 389-407). Mahwah, NJ: LEA.

\section{5}

B (1995). A Pragmatic Theory of Fallacy. Tuscaloosa, AL: University of Alabama Press. Walton, D. \& Krabbe, E.C.W. (1995). Commitment in Dialogue. Albany, NY: SUNY.

J (1995). Appeal to pity: A case study of the argumentum ad misericordiam. Arg, 9, 769-784. 
E (1995). Arguments, types of. In T. Honderich (Ed.), Oxford Companion to Philosophy (pp. 48-49). New York: OUP.

(1995). The essential ingredients of the fallacy of begging the question. In H.V. Hansen \&

R.C. Pinto (Eds.), Fallacies: Classical and Contemporary Readings (pp. 229-239).

University Park, PA: Penn Sate University Press.

(1995). Informal fallacy [Entry for]. In R. Audi (Ed.), The Cambridge Dictionary of Philosophy (pp. 372-376). New York: CUP.

(1995). Informal logic [Entry for]. In R. Audi (Ed.), The Cambridge Dictionary of Philosophy (p. 376). New York: CUP.

P (1995). The straw man fallacy. In F.H. van Eemeren et. al. (Eds.), Analysis and Evaluation, vol. 2 of Proceedings of the Third ISSA Conference on Argumentation (pp. 421-434). Amsterdam: SicSat.

\section{4}

J (1994). Begging the question as a pragmatic fallacy. Syn, 100, 95-131.

\section{3}

J (1993). Alethic, epistemic, and dialectical models of argument. $P \& R, 26,302-310$.

(1993). Commitment, types of dialogue, and fallacies. IL, 14, 93-103.

(1993). Introduction to philosophy and the argumentum ad hominem. Inq, 12, 24.

(1993). The normative structure of case study argumentation. Metaphilosophy, 24, 207-226.

(1993). The speech act of presumption. $P \& C, 1,125-148$.

Walton, D. \& Krabbe, E.C.W. (1993). It's all very well for you to talk! Situationally disqualifying ad hominem attacks. IL, 15, 79-91.

\section{2}

B (1992). Plausible Argument in Everyday Conversation. Albany, NY: SUNY.

(1992). Slippery Slope Arguments. Oxford: OUP. [Reprinted by Vale Press in 1999.]

(1992). The Place of Emotion in Argument. University Park, PA: PSUP.

J (1992). After analytic philosophy, what's next? An analytic philosopher's perspective. J of Speculative Philosophy, 6, 123-142.

(1992). Correctness of argument as a function of respondent's commitment. Canadian J of Rhetorical Studies, 2, 52-72.

(1992). Nonfallacious arguments from ignorance. $A P Q, 29,381-387$.

(1992). Rules for plausible reasoning. IL, 14, 33-51.

(1992). Which of the fallacies are fallacies of relevance? Arg, 6, 237-250.

E (1992). Burden of proof [Entry for]. In J. Dancy \& E. Sosa (Eds.), A Companion to Epistemology (p. 55). Oxford: Blackwell.

(1992). Circular reasoning [Entry for]. In J. Dancy \& E. Sosa (Eds.), A Companion to Epistemology (p. 66). Oxford: Blackwell.

(1992).Courage [Entry for]. In Encyclopedia of Ethics (pp. 220-223) New York: Garland Publishing Co.

(1992). Genetic fallacy [Entry for]. In J. Dancy \& E. Sosa (Eds.), A Companion to Epistemology (pp. 154-155). Oxford: Blackwell.

(1992). Informal fallacies [Entry for]. In J. Dancy \& E. Sosa (Eds.), A Companion to

Epistemology (pp. 212-216). Oxford: Blackwell.

(1992). Practical reasoning [Entry for]. In Encyclopedia of Ethics (pp. 996-1000). New York:

Garland Publishing Co.

(1992). Questionable questions in question period: Prospects for an informal logic of 
parliamentary discourse. In E.M. Barth \& E.C.W. Krabbe (Eds.), Logic and Political Culture (pp. 87-95). Amsterdam: Royal Netherlands Academy of Arts and Sciences.

(1992). Types of dialogue, dialectical shifts and fallacies. In F.H. van Eemeren et. al. (Eds.), Argumentation Illuminated (pp. 133-147). Amsterdam: SicSat.

\section{1}

B (1991). Begging the Question: Circular Reasoning as a Tactic of Argumentation. New York: Greenwood Press.

J (1991). Bias, critical doubt, and fallacies. A\&A, 28, 1-22.

(1991). Critical faults and fallacies of questioning. JP, 15, 337-366.

(1991). Hamblin on the standard treatment of fallacies. $P \& R$, 24, 353-361.

Walton, D. \& Krabbe, E.C.W. (1991). Gemakkelijk Praten! Situationeel Diskwalificerende Aanvallen Ad Hominem. Tijdschrift voor Taalbeheersing, 13, 108-119.

E (1991). Les violations des règles du dialogue raisonné. In H. Parret (Ed.), La Communauté en Paroles: Communication, Consensus, Ruptures (pp. 245-265). Liège: Editions Pierre Mardaga.

\section{0}

B (1990). Practical Reasoning: Goal-Driven, Knowledge-Based, Action-Guiding Argumentation. Savage, MD: Rowman \& Littlefield.

J (1990). Courage, relativism and practical reasoning. Philosophia, 20, 227-240.

(1990). Ignoring qualifications (secundum quid) as a subfallacy of hasty generalization. $L \& A$, 129/130, 113-154.

(1990). What is reasoning? What is an argument? The J of Philosophy, 87, 399-419.

E (1990). Types de dialogue et glissements dialectiques en argumentation. In M. Meyer \& A. Lempereur (Eds.), Figures et Conflicts Rhétoriques (pp. 227-239). Brussels: Editions de l'Université de Bruxelles.

\section{9}

B (1989). Informal Logic: A Handbook for Critical Argumentation. New York: CUP. (1989). Question-Reply Argumentation. New York: Greenwood Press.

Walton, D. \& Woods, J. (1989). Fallacies: Selected Papers 1972-1982. Dordrecht: Foris.

J (1989). Dialogue theory for critical thinking. Arg, 3, 169-184.

(1989). Problems in the use of expert opinion in argumentation. Communication \& Cognition, 22, 383-389.

(1989). Reasoned use of expertise in argumentation. Arg, 3, 59-73.

E (1989). Question-asking fallacies. In M. Meyer (Ed.), Questions and Questioning (pp. 195221). Berlin: Walter de Gruyter.

\section{8}

J (1988). Burden of Proof. Arg, 2, 233-254.

(1988). Reply to Thomas on models of courage. Dialogue, 27, 697-699.

P (1988). Argumentation and fallacies: The problems in teaching. In Philosophie et Culture, Actes/Proceedings: XVIIe Congrès Mondiale de Philosophie, vol. 5 (pp. 373-381). Montreal: Editions Montmorency.

\section{7}

B (1987). Informal Fallacies: Towards a Theory of Argument Criticisms. Amsterdam \& Philadelphia: John Benjamins.

J (1987). The ad hominem argument as an informal fallacy. Arg, 1, 317-331.

(1987). The virtue of courage. The World \& I, 12, 595-609. 


\section{6}

B (1986). Courage: A Philosophical Investigation. Los Angeles: University of California Press.

J Walton, D. and Donen, N. (1986). Ethical decision-making and the critical care team. Critical Care Clinics, 2, 101-109.

Walton, D. \& Hobbs, D.C. (1986). Non-treatment of spina bifida babies. Philosophy Research Archives, 11, 463-480.

E (1986). Chisholm's theory of action. In R.J. Bogdan (Ed.), Roderick Chisholm (pp. 169-913). Dordrecht: Reidel.

P (1986). What is a fallacy? In F.H. van Eemeren et. al. (Eds.), Argumentation: Across the Lines of Discipline (pp. 323-330). Dordrecht: Foris.

\section{5}

B (1985). Arguer's Position: A Pragmatic Study of Ad Hominem Attack, Criticism, Refutation and Fallacy. Westport, CT: Greenwood Press.

(1985). Physician-Patient Decision-Making: A Study in Medical Ethics. Westport, CT:

Greenwood Press.

J (1985). Are circular arguments necessarily vicious? APQ, 22, 263-274.

(1985). New directions in the logic of dialogue. Syn, 63, 259-274.

(1985). Pragmatic inferences about actions. Syn, 65, 211-233.

\section{4}

B (1984). Logical Dialogue-Games and Fallacies. Lanham, MD: University Press of America.

J (1984). Cans, advantages and possible worlds. Philosophia, 14, 83-97.

(1984). Death and dying in medicine: What questions are still worth asking? Theoretical Medicine, 5, 121-139.

Walton, D. \& Batten, L.H. (1984). Games, graphs and circular arguments. $L \& A, 106,133-164$.

\section{3}

B (1983). Ethics of Withdrawal of Life-Support Systems: Case Studies on Decision-Making in

Intensive Care. Westport, CT: Greenwood Press.

J (1983). Enthymemes. $L \& A, 103 / 104,395-410$.

\section{2}

B (1982). Topical Relevance in Argumentation. Amsterdam \& Philadelphia: John Benjamins. Walton, D. \& Woods, J. (1982). Argument: The Logic of the Fallacies. Toronto \& New York: McGraw-Hill Ryerson.

J (1982). Comments on a medical ethics for the future. Metamedicine, 3, 121-124.

(1982). Neocortical versus whole-brain conceptions of personal death. Omega: The J of Death and Dying, 12, 339-344.

(1982). Philosophy of medicine in Canada. Metamedicine, 3, 263-277.

Walton, D. \& Woods, J. (1982). Question-begging and cumulativeness in dialectical games. Noûs, 4, 585-605.

Walton, D. \& Woods, J. (1982). The petitio: Aristotle's five ways. CJP, 12, 77-100.

\section{1}

J (1981). Epistemology of brain death determination. Metamedicine, 2, 21-36.

(1981). Splitting the difference: Killing and letting die. Dialogue, 20, 68-78.

(1981). The fallacy of many questions. $L \& A, 95 / 96,291-313$.

(1981). What is logic about? IL, 4(1), 2-4.

Walton, D. \& Woods, J. (1981). More on fallaciousness and invalidity. $P \& R, 14,168-172$. 
E (1981). Lehrer on action, freedom and determinism. In R.J. Bogdan (Ed.). Keith Lehrer (pp. 107-128). Dordrecht: Reidel.

\section{0}

B (1980). Brain Death: Ethical Considerations. West Lafayette, IN: Purdue University Press.

J (1980). Cans and counterfactuals. CJP, 10, 489-496.

(1980). Critical study of Ingmar Pörn. Syn, 43, 421-431.

(1980). Ignoratio elenchi: The red herring fallacy. IL, 2(3), 3-7.

(1980). Omissions and other negative actions. Metamedicine, 1, 305-324.

(1980). Omitting, refraining, and letting happen. $A P Q, 17,319-326$.

(1980). On allowing something to happen. Man \& Medicine, 5, 167-176.

(1980). On the logical form of some commonplace action expressions. Grazer Philosophische

Studien, 10, 141-148.

(1980). Reply to commentaries. Man \& Medicine, 5, 185-188.

(1980). The ethical force of definitions. J of Medical Ethics, 6, 16-18.

(1980). Why is the ad populum a fallacy? $P \& R, 13,264-278$.

Walton, D. \& Fleming, W.H. (1980). Responsibility for discontinuation of treatment. Essence, 4, 57-61.

P (1980). Petitio principii and argument analysis. In R.H. Johnson \& J.A. Blair (Eds.), Informal Logic: The First International Symposium (pp. 41-54). Reyes, CA: Edgepress.

\section{9}

B (1979). On Defining Death: An Analytic Study of the Concept of Death in Philosophy and

Medical Ethics. Montreal: McGill-Queens University Press.

J (1979). Critical study on some recent action theory. Philosophia, 8, 719-740.

(1979). Philosophical basis of relatedness logic. Philosophical Studies, 36, 115-136.

(1979). Relatedness in intensional action chains. Philosophical Studies, 36, 175-223.

(1979). The active-passive distinction in ethical decision-making. Philosophy Research Archives, 5, no. 1350.

Walton, D. \& Epstein, R. (1979). Preface to relatedness logic issue. Philosophical Studies, 36, 113-114.

Walton, D. \& Woods, J. (1979). A brief guide to studying and teaching on the fallacies. Australian Logic Teacher's J, 3, 1-3.

Walton, D. \& Woods, J. (1979). Circular demonstration and von Wright-Geach entailment. Notre Dame J of Formal Logic, 20, 768-772.

Walton, D. \& Woods, J. (1979). Equivocation and practical logic. Ratio, 21, 31-43. [A German translation appears in the same issue.]

Walton, D. \& Woods, J. (1979). Laws of thought and epistemic proofs. Idealistic Studies, 9, 55-65.

Walton, D. \& Woods, J. (1979). What type of argument is an ad verecundiam? IL, 2(1), 5-6.

\section{8}

B Walton, D. \& Urban, L. (Eds.). (1978). The Power of God: Readings on Omnipotence and Evil. New York: OUP.

J (1978). The circle in the ontological argument. International J for Philosophy of Religion, 9 , 193-218.

Walton, D. \& Woods, J. (1978). Arresting circles in formal dialogues. J of Philosophical Logic, 7, 73-90.

Walton, D. \& Woods, J. (1978). Puzzle for analysis: Find the fallacy. IL, 1, 5-6.

Walton, D. \& Woods, J. (1978). The fallacy of ad ignorantiam. Dialectica, 32, 87-99. 
E (1978). Modalities in the free will defence. In D. Walton \& L. Urban (Eds.), The Power of God: Readings on Omnipotence and Evil (pp. 240-248) New York: OUP. [Reprinted from Religious Studies, 10, 1974, 325-331.]

Walton, D. \& Urban, L. (1978). Freedom within omnipotence. In D. Walton \& L. Urban (Eds.), The Power of God: Readings on Omnipotence and Evil (pp. 192-207) New York: OUP.

\section{7}

J (1977). Mill and DeMorgan on whether the syllogism is a petitio. International Logic Review, 8, 57-68.

(1977). Obstacles and opportunities. Philosophical Papers, 6, 11-20.

(1977). Performative and existential self-verifyingness. Dialogue, 16, 128-138.

(1977). Purtill on power and evil. International J for Philosophy of Religion, 8, 263-267.

Walton, D. \& Woods, J. (1977). Ad hominem. The Philosophical Forum, 8, 1-20.

Walton, D. \& Woods, J. (1977). Ad hominem contra Gerber. The Personalist, 58, 141-144.

Walton, D. \& Woods, J. (1977). Composition and division. Studia Logica, 36, 381-406.

Walton, D. \& Woods, J. (1977). Petitio and relevant many-premissed arguments. $L \& A, 20,97-$ 110.

Walton, D. \& Woods, J. (1977). Post hoc, ergo propter hoc. Review of Metaphysics, 30, 569 593.

Walton, D. \& Woods, J. (1977). Towards a theory of argument. Metaphilosophy, 8, 299-315.

1976

B Walton, D. \& Brand, M. (Eds.). (1976). Action Theory. Dordrecht: Reidel.

J (1976). A note on motives, consequences and value. The J of Value Inquiry, 10, 149-150.

(1976). Active and passive euthanasia. Ethics, 86, 269-274.

(1976). Intensional action theory. Philosophy Research Archives, 2, No. 1149.

(1976). Logical form and agency. Philosophical Studies, 29, 75-89.

(1976). On logic and methodology in the study of death. Ethics in Science and Medicine, 3, 135-147.

(1976). On the rationality of fear of death. Omega: The J of Death and Dying, 7, 1-10.

(1976). Principles of interpersonal agency in the free will defense. Bijdragen; Tijdschrift Voor

Filosophie en Theologie, 37, 36-46.

(1976). Some considerations on the nihil obstat analysis of the modal auxiliary verb can. Studia Anglica Posnaniensia, 8, 55-63.

(1976). St. Anselm and the logical syntax of agency. Franciscan Studies, 36, 298-312.

(1976). Some theorems of Fitch on omnipotence. Sophia, 15, 20-27.

(1976). The formalities of evil. Critica, 8, 3-9.

(1976). The logic of ability. Philosophy Research Archives, 2, No. 1068.

Walton, D. \& Woods, J. (1976). Ad baculum. Grazer Philosophische Studien, 2, 133-140.

Walton, D. \& Woods, J. (1976). Fallaciousness without invalidity? $P \& R, 9,52-54$.

E (1976). Time and modality in the 'can' of opportunity. In M. Brand \& D. Walton (Eds.),

Action Theory, (pp. 271-287). Dordrecht: Reidel.

1975

J (1975). Can, determinism, and modal logic. The Modern Schoolman, 52, 381-390.

(1975). Ifs and cans: Pros and cons. The Personalist, 56, 242-249.

(1975). Language, God and evil. International J for Philosophy of Religion, 6, 154-162. 
(1975). Modal logic and agency. $L \& A, 69 / 70,103-111$.

(1975). Philosophical perspectives on the insanity defense. The Human Context, 7, 546-560. Walton, D. \& Woods, J. (1975). Is the syllogism a petitio principii? Mill News Letter, 10, 13-

15 .

Walton, D. \& Woods, J. (1975). Moral expertise. J of Moral Education, 5, 13-18.

Walton, D. \& Woods, J. (1975). Petitio principii. Syn, 31, 107-127.

\section{4}

J (1974). Control. Behaviorism, 2, 162-171.

(1974). Modalities in the free will defence. Religious Studies, 10, 325-331.

Walton, D. \& Woods, J. (1974). Argumentum ad verecundiam. $P \& R, 7,135-153$. [Dutch translation in (1997), F.H. van Eemeren \& R. Grootendorst (Eds.), Studies Over Argumentatie (pp. 191-210). Amsterdam: Boom.]

Walton, D. \& Woods, J. (1974). Informal logic and critical thinking. Education, 95, 84-86.

P (1974). St. Anselm on the verb 'to do' (facere). Proceedings of the Linguistic Circle of Manitoba and North Dakota, 14, 9-12.

\section{3}

J (1973). Issues of explanation in linguistic theory. Manitoba Modern Languages Association Bulletin, 8, 19-25.

(1973). Power and causal possibility. CJP, 3, 281-284.

(1973). The contemporary relevance of Hume's remarks on liberty and necessity. J of Thought, 8, 183-188.

Walton, D. \& Shamburg, N. (1973). The principles of freedom and dignity in social technology. $J$ of Social Philosophy, 4, 8-11.

1972

J Walton, D. \& Woods, J. (1972). On fallacies. The J of Critical Analysis, 4, 103-111.

P (1972). Mathematical logic and empirical linguistics. Proceedings of the Linguistic Circle of Manitoba and North Dakota, 12, 13-15.

1971

P (1971). The modal auxiliary verb can: Some semantic problems. Proceedings of the Linguistic Circle of Manitoba and North Dakota, 11, 17-19. 